\title{
Restoration of native Atlantic salmon runs in northern Spain: do costs outweigh benefits?
}

\author{
F. Juanes ${ }^{(1)}$, S. Gephard(2), J. De La Hoz ${ }^{(3)}$, P. Moran ${ }^{(4)}$, E. Dopico(5), \\ J.L. Horreo ${ }^{(6)}$, E. Garcia-Vazquez ${ }^{(6) *}$
}

Received December 3, 2011

Revised May 19, 2011

Accepted November 9, 2011

Key-words: population restoration, habitat assessment, Salmo salar

\section{ABSTRACT}

Atlantic salmon stocks in northern Spain are at the southern range of the species distribution. As such they are likely more vulnerable to environmental change and human disturbance. The Nalon-Narcea River salmon is one such population in Asturias, Spain. The river is dammed throughout the watershed with few fish passage facilities. However, angling data show that salmon returns are consistent although the population is relatively small. We have employed one tributary as a model, the River Trubia. Although some problems of agriculture and industrial pollution have been detected downstream, an upstream habitat evaluation suggests that adequate spawning and juvenile habitat exists. The regional Government has proposed to construct fishways for allowing upstream passage of salmon. This would potentially increase salmon production, but there are also some concerns like increased hybridization of salmon and trout which is already evident downriver and which previous work suggests will increase as salmon colonize new habitat, and potential changes in fishing regulations as salmon distributions shift upriver and away from traditional angling areas. Here, we present an overview of ecological and social aspects of salmon habitat restoration in the River Nalon-Narcea that we hope will provide solutions that balance costs and benefits and may be applicable to other anadromous populations.

\section{RÉSUMÉ}

La restauration du saumon de l'Atlantique natif fonctionne dans le nord de l'Espagne : les coûts dépassent-ils les avantages?

Mots-clés : restauration de population, évaluation de I'habitat, Salmo salar
Les stocks de saumon atlantique dans le nord de l'Espagne sont à la limite sud de la distribution de l'espèce. Comme tels, ils sont probablement plus vulnérables aux changements environnementaux et aux perturbations humaines. Le saumon de la rivière Nalon-Narcea est une de ces populations dans les Asturies, en Espagne. La rivière est endiguée, avec quelques passes à poissons. Toutefois, les données de pêche montrent que les retours de saumon sont bons bien que la population soit relativement faible. Nous avons employé un affluent comme modèle, la rivière Trubia. Bien que certains problèmes de pollution agricole et

(1) University of Massachusetts, Department of Environmental Conservation, Amherst, MA, USA

(2) Connecticut Department of Environmental Protection, Inland Fisheries Division, Old Lyme, CT, USA

(3) Servicio de Caza y Pesca, Principado de Asturias, Oviedo, Spain

(4) Departamento de Bioquímica, Xenética e Inmunoloxía, Universidade de Vigo, Spain

(5) Departamento de Ciencias de la Educacion, Universidad de Oviedo, Spain

(6) Departamento de Biologia Funcional, Universidad de Oviedo, Spain

*Corresponding author: egv@uniovi.es 
industrielle soient détectés en aval, une évaluation de l'habitat de frai et juvénile amont suggère que l'habitat adéquat existe. Le gouvernement régional a proposé de construire des passes à poissons pour permettre le passage amont du saumon. Ce serait potentiellement augmenter la production de saumon, mais il y a aussi certaines préoccupations, comme l'hybridation accrue du saumon et de la truite qui est déjà évidente en aval. Des travaux antérieurs suggèrent que ceci va augmenter avec le saumon qui colonise de nouveaux habitats, et les changements potentiels dans les règlements de la pêche au saumon avec ce changement distribution amont, loin des zones de pêche traditionnelles. Ici, nous présentons un aperçu des aspects écologiques et sociaux de la restauration de l'habitat du saumon dans la rivière Narcea-Nalon qui, nous l'espérons, offriront des solutions qui équilibreront les coûts et les bénéfices et pourront être applicables à d'autres populations anadromes.

\section{INTRODUCTION}

Atlantic salmon (Salmo salar) populations have declined worldwide due to many factors but the construction of dams is an important factor (Parrish et al., 1998). Dams have blocked the migration of adult salmon and prevented them from spawning in upstream habitat. This has resulted in fewer smolts emigrating to the ocean and therefore fewer adults returning to freshwater. Many governments are attempting to restore Atlantic salmon runs above these dams, including the Asturias province in Spain (De La Hoz, 2001). The River Nalon-Narcea (Figure 1) is a large basin that historically supported a large salmon run (Ventura, 1988) but was fragmented by a series of dams in the mainstem and in various tributaries, the oldest constructed in 1959, which restricted the accessible portion of the river to $1 / 3$ of the original area. A restoration effort has begun. Fish passes (their cost was about $420000 €$.fish ${ }^{-1}$ pass on average) have been built on three dams on the River Nalon-Narcea and at one dam on the River Trubia, a major tributary of the River Nalon, but there are no plans to build fish passes at the dams on the headwater tributaries of the River Trubia. Damming is not the only environmental problem detected in the River Trubia, pollution by heavy metals (Ayllon et al., 2000) and some diffuse agricultural pollution (Dopico et al., 2009) have also been reported. Salmon restoration programs in other regions, like in the United States, have focused on building fish passes at dams when abundant habitat exists upstream of the dams (Moffitt et al., 1982). Government agencies in the US have stocked salmon fry (age 0) into good salmon habitat above dams without fish passes to allow that habitat to produce smolts even before the fish passes are built (Gephard, 2008).

This approach could be effectively used in Spanish watersheds with high-quality juvenile salmon habitat that is easily accessible by roads and could be easily stocked with fry. However, restoration would be less successful for purposes of conservation of natural diversity if the native salmon population suffered from altered genetic diversity. Reduced habitat encompasses biological risks that directly affect within-species diversity. One of them is increasing interactions between species that share the available habitat. In northern Spain, brown trout, Salmo trutta, coexist with Atlantic salmon. The two species hybridize naturally and interspecific introgression has been reported in the River Narcea-Nalon (Garcia-Vazquez et al., 2001), partially associated with past stock transfers (Castillo et al., 2008). It is likely that hybridization has been promoted by reduction of spawning areas in the Narcea-Nalon basin, forcing overlap of brown trout and Atlantic salmon reds when breeder densities were high due to abundant sea runs. Hybridization is not the only phenomenon likely to occur between salmon and trout. Competition usually leads to a shift of salmon juveniles toward suboptimal habitats; brown trout being more aggressive (Heggenes et al., 1999). Population reduction can also cause a decrease of effective population size, with associated losses of genetic variability and increased inbreeding. On the other hand, it has also been argued that disturbance of native salmon populations in the region was caused by introgression of foreign genomes of the same species derived from past stock transfers from northern European countries (i.e. 


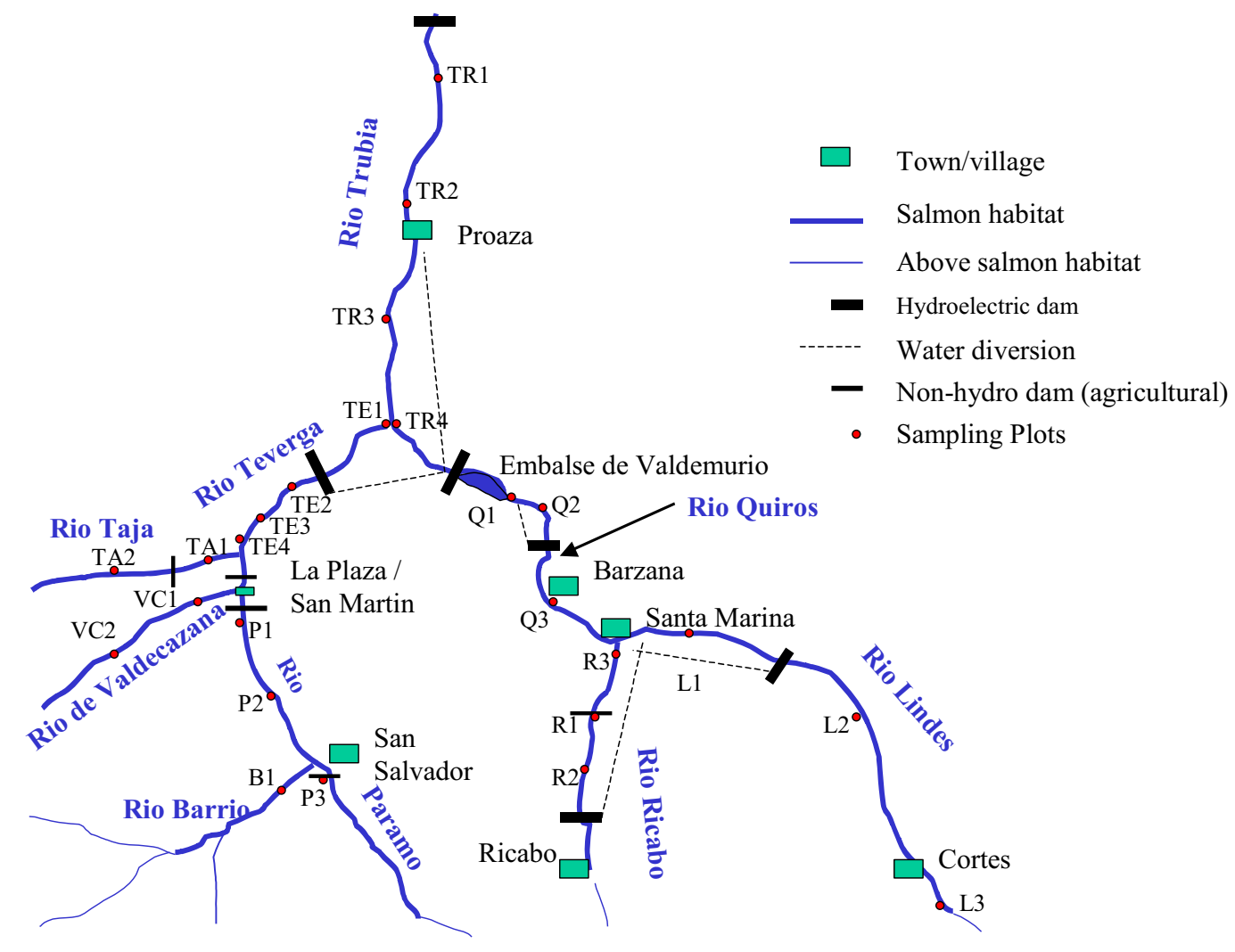

Figure 1

Map of the River Trubia watershed and study plots.

Figure 1

Carte du bassin versant de la rivière Trubia et des sites d'étude.

Moran et al., 2005; Ayllon et al., 2006). To ensure reasonable success of restoration efforts, the status of the extant population should be first assessed by estimating the level of inbreeding and introgression of foreign genomes (hetero or homo-specific, which could be derived from past stock transfers).

Restoration efforts often encompass enormous costs, both economic and social, for users. For example, special regulations of sport fisheries would be implemented in upstream tributaries soon after salmon stocking above dams, which would include restrictions or even banning of brown trout angling. These rules will be more efficient, better received and accomplished, if management actions are supported by the resource users. Involvement of users in management ensures the implementation of conservative practices if they are supported by a critical mass of citizens (Stake, 1995). In Asturias, users participate in population management through angler associations that collaborate with the regional Administration by hatchery rearing both Atlantic salmon and brown trout with purposes of population enhancement. Therefore it is necessary to understand the motivations and opinions of the fishermen before planning big changes such as stocking new river areas.

The objectives of this paper are to: (1) estimate the available habitat in the River Trubia watershed by measuring subsamples of habitat throughout the entire watershed, (2) provide estimates of how many smolts, and subsequently adults, the watershed could generate if stocked with salmon fry, (3) determine the status of conservation of the native gene pool of the River Nalon-Narcea Atlantic salmon, focusing on the level of genetic variability and introgression of foreign (homo- and heterospecific) genomes, and (4) survey the opinions of users on management measures to be promoted in the River Nalon-Narcea. 


\section{METHODS}

\section{> CATCH STATISTICS AND FOREIGN STOCKING RECORDS}

Both annual catch and foreign stocking records were obtained from the Regional Government of Asturias (Principado de Asturias, Spain).

\section{> ESTIMATES OF AVAILABLE SALMON HABITAT IN THE RIVER TRUBIA}

During multiple visits to River Trubia watershed nine streams were identified as possessing significant amounts of juvenile salmon habitat: Ríos Trubia, Teverga, Paramo, Taja, deValdecazana, Barrio, Quiros, Lindes, and Ricabo. The downstream limit of the survey (on the Río Trubia) was the upstream boundary of the impoundment behind the dam in Trubia ( $2.5 \mathrm{~km}$ upstream of the River Nalon). We did not survey habitat below the dam. Field observations were made to identify the upstream limit of usable juvenile salmon habitat in each surveyed tributary in the watershed. This location was marked on a map and the total linear metres of habitat present between this upstream location and the mouth of the river (downstream limit) was estimated by map measurement. "Zones" of relatively homogenous size, habitat type, and morphology were identified along the length of the streams. The linear distance of each stream zone was also estimated by map measurement.

We established and surveyed sample plots in the summer of 2001 during periods of low streamflow. Between two and four sample plots ranging in length from 100 to $200 \mathrm{~m}$ were surveyed. (Only one sample plot was surveyed on the Río Barrio due to its small size and poor access.) These sample plots were chosen as being typical for stream habitat within a stream zone. Figure 1 shows the surveyed streams and the locations of the sample plots. For each plot, the following data were collected: total length, three stream widths, three stream depths for each width transect, substrate composition, ratio of pools to riffles, amount of instream and overhead cover, and water temperature (definitions in Stanley and Trial, 1995). Within each plot, each meter of habitat was assigned to one of the following salmon habitat designations: fry (age 0), parr (age 1), adult spawning, adult resting, adult holding, no value. Habitat designations were assigned based on well-accepted standards (Stanley and Trial, 1995) and the judgment of the authors who have extensive experience with Atlantic salmon and salmon habitat in the US and other countries. Later, these data were analyzed and the amount of each habitat type was calculated in standard salmon production units $\left(100 \mathrm{~m}^{2}\right)$. Temperature data were collected to assess habitat suitability for Atlantic salmon (as defined by De Cola, 1970; McLaughlin and Knight, 1987). The surveyors performed qualitative assessments of water quality without taking any measurements (other than water temperature). The presence of water pollution was assumed based on the appearance of discoloration, odor, and suspended solids. No attempt was made to characterize or measure this pollution.

Total amount of juvenile salmon ('rearing') habitat in each stream zone was calculated using the formula:

$$
E R U=A \times B
$$

where: $E R U=$ Estimated Rearing Units; $A=$ number of measured units in the sample plot; $B=$ number of meters in the zone of the stream/number of meters in the sample plot. All habitat 'units' are $100 \mathrm{~m}^{2}$, a standardized areal measurement common to all Atlantic salmon studies. The ERUs for each stream zone were added to estimate the total number of rearing units for each stream. ERUs were subtotaled by sub-basin (Trubia, Teverga, and Quiros) and added to calculate a grand total for the entire basin.

\section{> ESTIMATES OF POTENTIAL SMOLT PRODUCTION AND ADULT HARVEST IN THE RIVER TRUBIA}

In order to demonstrate the potential production capacity of the surveyed habitat, typical smolt production rates were estimated based on the scientific literature. Such rates have been 
reported extensively for other countries but little such work has been done in Spain. The Spanish rivers are often different than rivers in most other European countries and typical production rates in these other countries should be used with caution. Ventura (1988) reported $65 \%$ of all parr became smolts after one year and the rest of the parr became smolts after two years in Asturian rivers (but see Nicieza et al. (1991) who reported differing rates for the Narcea and Esva rivers in Asturias). He reported average parr densities of 18.75/100 $\mathrm{m}^{2}$ but did not provide individual densities for the two year classes of parr. Braña et al. (1995) reported fall and winter densities ranging from 15 to $38 / 100 \mathrm{~m}^{2}$ but no overwinter mortality data for rivers in the Spanish Cantabrian region. In a paper summarizing smolt production rates and densities, Bagliniere and Champigneulle (1986) reported smolt densities for European rivers ranging from $1-7 / 100 \mathrm{~m}^{2}$. From this summary and previous work in Spanish rivers we proposed a range of smolt production rates for Spanish rivers which we could use to estimate adult production. We designated 5 as a "high" smolt rate based on data from UK rivers which would experience similar temperature regimes. We arbitrarily chose two lower production rates: "medium" at 3.5 smolts $/ 100 \mathrm{~m}^{2}$ based on the mean rate observed by Bagliniere and Champigneulle (1986) for the Scorff River in Brittany and by Bagliniere et al. (2005) for the Oir River in lower Normandy, and "low" at 1.1 smolts $/ 100 \mathrm{~m}^{2}$ matching the lowest rates found in European rivers.

Similar to smolt production rates, little work has been done in Spain to estimate adult return rates from smolt rates. However, Garcia de Leaniz and Martinez (1986) used a model for the River Asón that estimated a value of 0.05 for an adult return rate. Álvarez et al. (1995) reported a return rate of 0.98 to $6.14 \%$ from a mark-and-recapture study on stocked fish on the River Bidasoa. This river has been greatly degraded from dams, water removals, and pollution (Álvarez et al., 1995; Gorka Sancho, College of Charleston, personal communication) and it would seem that salmon in high quality streams in Asturias should experience higher return rates than salmon in the River Bidasoa. Therefore, we arbitrarily chose 0.08 as a "high" return rate, 0.04 as a "medium" return rate and 0.01 as a "low" return rate.

We multiplied the three levels of smolt production rates by the estimated number of rearing units (ERUs) for each stream to calculate a range of smolts that might be produced by each stream in a typical year. We multiplied the three levels of smolt production by the three levels of estimated adult return rates to calculate a range of estimated adult returns that could be supported by the habitat.

\section{$>$ GENETIC ANALYSES}

Interspecific hybridization was detected employing species-specific markers as described in Castillo et al. (2008). Samples of Atlantic salmon and brown trout juveniles $(n>1000)$ were collected by electrofishing in different years and stored frozen $\left(-20^{\circ} \mathrm{C}\right)$ or in absolute ethanol in our laboratory until genetic analysis. Age was determined from scales (Rifflart et al., 2006) to calculate the cohort of each individual sampled. In total we obtained samples from eight cohorts (1987, 1989-1992, 1995, 1996 and 2003).

The levels of genetic variability, inbreeding and introgression of foreign homospecific genomes, based on enzymatic and microsatellite loci, were calculated as described in previous publications (e.g. Moran et al., 2005; Ayllon et al., 2006; Horreo et al., 2008). Data published therein were compiled for this study.

\section{> INTERVIEW SURVEY OF ANGLERS}

Open interviews have been identified as a useful resource for tackling public opinion on conservation issues (Dopico et al., 2009). We carried out a survey based on 250 individual personal interviews. Anglers were interviewed on the river banks, while they were fishing in June and July 2004. We performed 50 interviews per river in the five main Asturian rivers (Cares, Sella, Narcea, Esva and Eo rivers, from east to west). The questions were open and multiple responses were admitted, following McKernan (1991). The participants were previously 


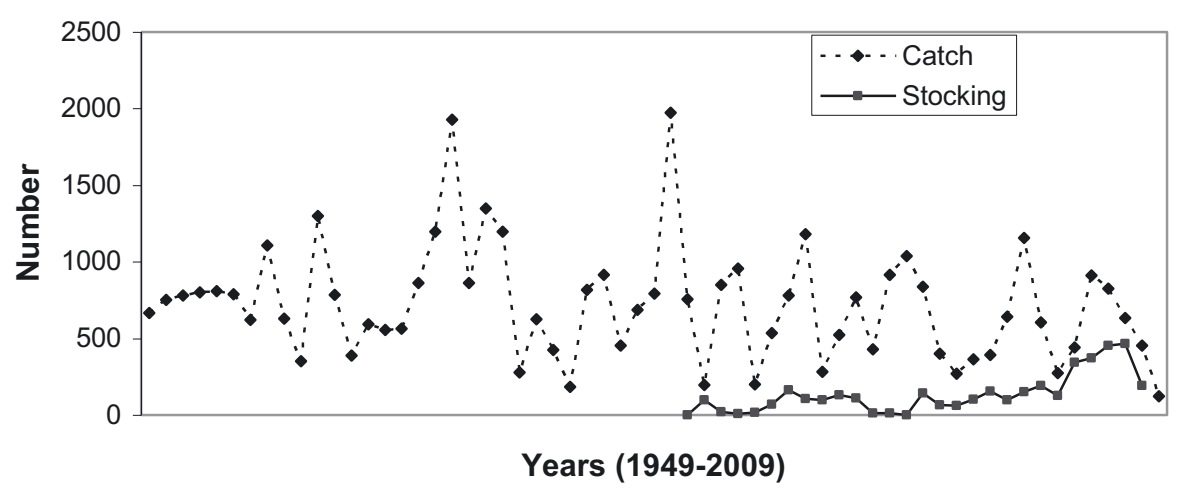

\section{Figure 2}

Sport catch and thousands of juveniles stocked into the River Nalon-Narcea since 1949 and 1981, respectively. In 2009 the river was not stocked.

\section{Figure 2}

Captures de pêche de loisirs et milliers de juvéniles déversés dans la rivière Nalon-Narcea de 1949 à 1981. En 2009, la rivière n'était pas alevinée.

informed about the objectives of the interview and confidentiality was guaranteed. The following items were considered:

(1) age;

(2) associative status (whether the participant belonged to an Association collaborating with the Administration);

(3) how the participant learned his/her knowledge about Atlantic salmon and angling practices;

(4) what was his/her perception about the status of the Atlantic salmon population in the River Nalón-Narcea during the last decade (this was the only closed question, with four possible answers suggested: (a) Stable; (b) Declining; (c) Increasing; (d) Unknown);

(5) problems (perceived by the participant) that negatively affected local Atlantic salmon populations;

(6) solutions suggested for improving the River Nalon-Narcea Atlantic salmon population.

The answers were copied into a field notebook. Incomplete or inconsistent interviews (less than $8 \%)$ were discarded and other persons were interviewed in order to complete a final number of 250 interviews. The answers were arranged into simple main categories and presented as percentages.

\section{RESULTS}

\section{$>$ CATCH AND STOCKING TRENDS}

The River Nalon-Narcea exhibited pronounced oscillations in the number of sport catches since 1949 (Figure 2), ranging from 1975 in 1980 to 122 in 2009. The linear regression was negative but not significant (slope $=-0.222,61$ d.f., $p=0.07$ ). In spite of a high stocking effort since 1981, that increased significantly $(r=0.710,26$ d.f., $p<0.001)$ up to 465000 juveniles released in 2007, annual catch did not increase over the last three decades (Figure 2) and stocking was not statistically associated with catch $(r=0.024,-0.249$ and -0.267 for correlation between the number of juveniles stocked and catch one, two and three years later respectively, $p>0.05$ in all cases). The origin of the stocked juveniles has been autochthonous (they were obtained from artificial spawning of returning adults) since 1992. 


\section{>PERCEPTIONS AND OPINIONS OF SALMON RESOURCE USERS}

The anglers interviewed in this study were 54.5 years old on average. Their knowledge about angling and salmon populations had been orally transmitted by relatives (family tradition) in most cases (85\%). Most anglers (71\%) were members of a fishing Association, thus they were directly involved in management of salmonid populations.

With respect to anglers' perception of the status of salmon populations in the region, $81 \%$ participants in the survey declared that Atlantic salmon had been declining in the Asturian rivers during the last few years. Many anglers identified more than one problem as the hypothetical cause for population declines, these included: predators (85\%), environmental degradation (52\%), inefficient management / insufficient staff for controlling freshwater fisheries $(54 \%)$, overfishing at sea (39\%), overfishing in freshwater $(27 \%)$, and other reasons such as illegal catches (11\%). Only $10 \%$ of the anglers identified dams and obstacles to fish migration as a main reason for population declines.

Two main solutions were suggested by most participants in the survey: control of predator population sizes (81\%), and stocking (78\%). Many fishermen (53\%) also considered that environmental restoration could contribute to stop salmon population declines, while $36 \%$ suggested an extension of banning periods / areas preserved from fisheries, and $28 \%$ demanded an increase in the numbers of personnel involved in vigilance tasks to prevent illegal catches. Anglers' preference for native stocks emerged spontaneously from question number 5: although most anglers who suggested stocking as a possible way to increase salmon population sizes did not differentiate between foreign and native stocking, native fish were preferred over foreign stocks in $14 \%$ of cases.

\section{> POTENTIAL SALMON PRODUCTION UPSTREAM OF THE RIVER TRUBIA DAMS}

All nine streams possessed considerable amounts of good quality juvenile salmon habitat (Table I). The sub-sampling was extrapolated to generate estimates of total ERUs per stream. Estimates ranged from 179 units (River Barrio) to 2372 units (River Trubia). The River Trubia sub-basin had the most ERUs (2372), followed by the River Teverga (1823) and the River Quiros sub-basins (1288) (Table I). The quality of the salmon habitat in the Trubia sub-basin was generally inferior to that in the other two sub-basins due to water removals and pollution downstream of Proaza. Water temperatures ranged from $14-18^{\circ} \mathrm{C}$ which are ideal for Atlantic salmon in the summer (De Cola, 1970; McLaughlin and Knight, 1987).

We estimated that the entire River Trubia watershed could produce between 6000 and 27000 smolts, if stocked so that it could achieve its full capacity (Table II). These levels of smolt production could then result a range of 60 to 2193 adult sea returns to the mouth of the River Nalon (Table II).

\section{>INTERSPECIFIC HYBRIDIZATION}

Interspecific hybrids were detected in the River Nalon-Narcea (Figure 3) in different years, with hybrid proportions ranging from 0.96 to $9.37 \%$. Hybrids were significantly positively associated with the sport catch of the previous year $(r=0.828,6$ d.f., $p<0.02)$, indicating that large sea runs (i.e. abundance of adult salmon) promoted hybridization.

\section{> POPULATION GENETIC VARIABILITY}

The genetic variability of this population is summarized in Table III. The parameters of withinpopulation genetic variability, particularly relatedness which was negative, indicate that the degree of inbreeding is negligible for the River Nalon-Narcea, as it is for the rest of populations in the region. Allelic richness, heterozygosity expected and observed for microsatellite loci were also similar to those of the neighbouring populations. The $F_{I S}$ value, indicator of withinpopulation homozygote excess, was relatively low and similar to that of the region. Finally, the 
Table I

Estimates for total units $\left(100 \mathrm{~m}^{2}\right)$ of rearing habitat based on extrapolations of sub-sampling plots. The number of rearing units (fry and parr habitat units) was estimated from the habitat sampling. Ratio is the number of meters in the zone of the stream divided by the number of meters in the sample plot. ERU is the estimated number of rearing units in the stream and is calculated as the number of rearing units multiplied by the ratio.

\section{Tableau I}

Estimations du total des unités $\left(100 \mathrm{~m}^{2}\right)$ d'habitat propice aux juvéniles faites par extrapolations du sous-échantillonnage de sites. Le nombre d'unités (alevins et tacons par unités d'habitat) a été estimé à partir de l'échantillonnage de l'habitat. Le rapport est le nombre de mètres dans la zone de la rivière divisé par le nombre de mètres du site. ERU est le nombre estimé d'unités dans le ruisseau et se calcule comme le nombre d'unités multiplié par ce rapport.

\begin{tabular}{|c|c|c|c|c|c|c|}
\hline Stream & Plot & $\mathrm{m}$ & \# Rearing units & $\mathrm{km}$ & Ratio & ERU \\
\hline \multirow[t]{5}{*}{ Trubia } & TR1 & 200 & 30.73 & 9 & 45 & 1382.85 \\
\hline & TR2 & 200 & 6.08 & 5 & 25 & 152 \\
\hline & TR3 & 200 & 30.49 & 4 & 20 & 609 \\
\hline & TR4 & 200 & 12.18 & 3.75 & 18.75 & 228.37 \\
\hline & \multicolumn{3}{|c|}{ Stream total- } & 21.75 & & 2372.22 \\
\hline \multirow[t]{5}{*}{ Teverga } & TE1 & 200 & 6.66 & 2 & 10 & 66.60 \\
\hline & TE2 & 200 & 12.26 & 3 & 15 & 183.90 \\
\hline & TE3 & 200 & 19.03 & 2 & 10 & 190.30 \\
\hline & TE4 & 200 & 6.99 & 3.85 & 19.25 & 134.55 \\
\hline & \multicolumn{3}{|c|}{ Stream total- } & 10.85 & & 575.35 \\
\hline \multirow[t]{4}{*}{ Paramo } & $\mathrm{P} 1$ & 100 & 8.7 & 2 & 20 & 174.00 \\
\hline & P2 & 100 & 4.67 & 2 & 20 & 93.40 \\
\hline & P3 & 100 & 7.47 & 2.38 & 23.8 & 177.79 \\
\hline & \multicolumn{3}{|c|}{ stream total- } & 6.38 & & 445.19 \\
\hline \multirow[t]{3}{*}{ Taja } & T1 & 100 & 9.3 & 2 & 20 & 186.00 \\
\hline & T2 & 100 & 4.9 & 3.5 & 35 & 171.50 \\
\hline & \multicolumn{3}{|c|}{ Stream total- } & 5.5 & & 357.50 \\
\hline \multirow[t]{3}{*}{ Valdecazana } & V1 & 100 & 4.9 & 2 & 20 & 98.00 \\
\hline & V2 & 100 & 5.6 & 3 & 30 & 168.00 \\
\hline & \multicolumn{3}{|c|}{ Stream total- } & 5 & & 266.00 \\
\hline \multirow[t]{2}{*}{ Barrio } & B1 & 100 & 5.97 & 3 & 30 & 179.10 \\
\hline & \multicolumn{3}{|c|}{ Stream total- } & 3 & & 179.10 \\
\hline \multirow[t]{4}{*}{ Quiros } & Q1 & 200 & 15.54 & 1 & 5 & 77.7 \\
\hline & Q2 & 200 & 11.9 & 3 & 15 & 178.5 \\
\hline & Q3 & 200 & 8.53 & 3.5 & 17.5 & 149.27 \\
\hline & \multicolumn{3}{|c|}{ Stream total- } & 7.5 & & 405.47 \\
\hline \multirow[t]{4}{*}{ Lindes } & L1 & 100 & 6.37 & 4 & 40 & 254.8 \\
\hline & L2 & 100 & 7.13 & 3 & 30 & 213.9 \\
\hline & L3 & 100 & 4.77 & 3 & 30 & 143.1 \\
\hline & \multicolumn{3}{|c|}{ Stream total- } & 10 & & 611.8 \\
\hline \multirow[t]{4}{*}{ Ricabo } & R3 & 100 & 4.97 & 1 & 10 & 49.7 \\
\hline & R1 & 100 & 6.27 & 2 & 20 & 125.4 \\
\hline & $\mathrm{R} 2$ & 100 & 4.76 & 2 & 20 & 95.2 \\
\hline & \multicolumn{3}{|c|}{ Stream total- } & 5 & & 270.3 \\
\hline
\end{tabular}




\section{Table II.}

Estimates for smolt production and adult returns for habitat in the River Trubia watershed. The number of units is extrapolated from Table II. Return rates are multiplied by corresponding smolt production rate (i.e., low $\times$ low, high $\times$ high) to obtain numbers of returning adults.

\section{Tableau II}

Estimations de la production de smolts et des retours d'adultes pour I'habitat dans le bassin de la rivière Trubia. Le nombre d'unités est extrapolé à partir du tableau II. Les taux de retour sont multipliés par le taux de production de smolts correspondante (par exemple, faible $\times$ faible, fort $\times$ fort) pour obtenir le nombre d'adultes qui reviennent.

\begin{tabular}{|l|c|c|c|c|c|c|c|c|c|}
\hline \multirow{2}{*}{ River } & & & \multicolumn{2}{|c|}{ Smolt production rates } & \multicolumn{3}{|c|}{ Adult sea return rates } \\
\cline { 2 - 9 } & \# of Units & Fry Needed & Low & Medium & High & Low & Medium & High \\
\cline { 2 - 9 } & & $(35 /$ unit) & $(1.1 /$ unit) & $(3.5 /$ unit) & $(5.0 /$ unit) & 0.01 & 0.04 & 0.08 \\
\hline Trubia & 2372.22 & 83027.7 & 2609.442 & 8302.77 & 11861.1 & 26.09442 & 332.1108 & 948.888 \\
\hline Teverga & 575.35 & 20137.25 & 632.885 & 2013.725 & 2876.75 & 6.32885 & 80.549 & 230.14 \\
\hline Paramo & 445.19 & 15581.65 & 489.709 & 1558.165 & 2225.95 & 4.89709 & 62.3266 & 178.076 \\
\hline Taja & 357.5 & 12512.5 & 393.25 & 1251.25 & 1787.5 & 3.9325 & 50.05 & 143 \\
\hline Valdecazana & 266 & 9310 & 292.6 & 931 & 1330 & 2.926 & 37.24 & 106.4 \\
\hline Barrio & 179.1 & 6268.5 & 197.01 & 626.85 & 895.5 & 1.9701 & 25.074 & 71.64 \\
\hline Subtotal & 1823.14 & 63809.9 & 2005.454 & 6380.99 & 9115.7 & 20.05454 & 255.2396 & 729.256 \\
\hline \multicolumn{7}{|c|}{} \\
\hline Quiros & 405.47 & 14191.45 & 446.017 & 1419.145 & 2027.35 & 4.46017 & 56.7658 & 162.188 \\
\hline Lindes & 611.80 & 21413 & 672.98 & 2141.3 & 3059 & 6.7298 & 85.652 & 244.72 \\
\hline Ricabo & 270.3 & 9460.5 & 297.33 & 946.05 & 1351.5 & 2.9733 & 37.842 & 108.12 \\
\hline Subtotal & 1287.57 & 45064.95 & 1416.327 & 4506.495 & 6437.85 & 14.16327 & 180.2598 & 515.028 \\
\hline
\end{tabular}

level of introgression of foreign genomes measured in 1992 (based on enzymatic loci) and in 1996 (based on microsatellite loci) was always the lowest in the region, as reflected by 1.5 and $5 \%$ individuals of foreign origin in 1992 and 1996 respectively, versus a $3 \%$ and $6.68 \%$ regional average in the same years.

\section{DISCUSSION}

Most participants in the survey suggested control of predator population sizes (81\%), and stocking $(78 \%)$ as main solutions for the perceived problems. Freshwater fish predators in the region are principally cormorants Phalacrocorax carbo and grey herons Ardea cinerea. These birds can, in some situations, remove large numbers of fish from stocked and natural fisheries (Harris et al., 2008). In the studied region there are controlled discards for population control of cormorants, which are shot and killed each year by river managers although fishermen 


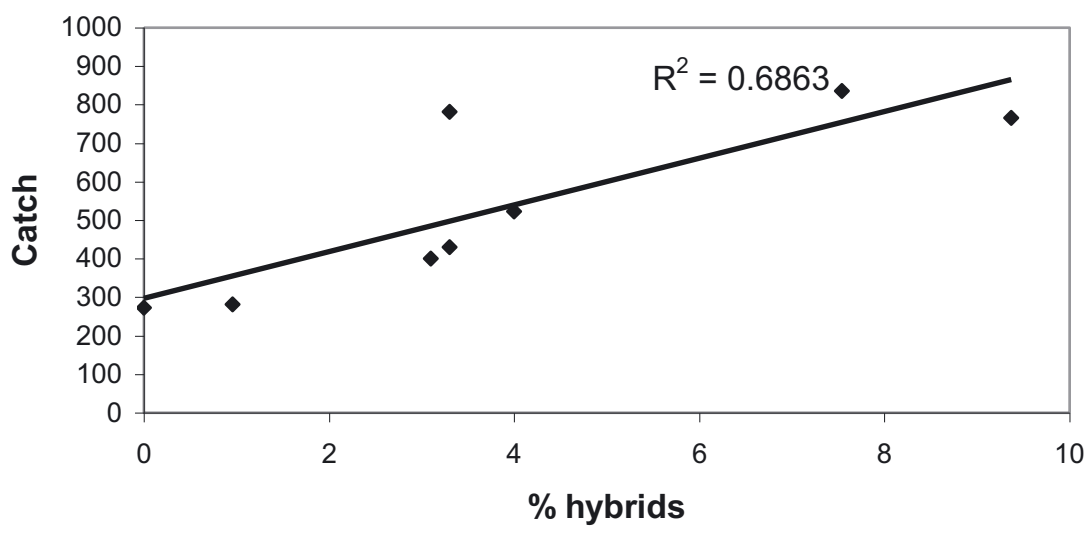

\section{Figure 3}

Relationship between percent of hybrids of a cohort and number of adults legally caught by anglers the previous year (as indicator of the breeding population size).

\section{Figure 3}

Relation entre le pourcentage d'hybrides d'une cohorte et le nombre d'adultes légalement capturés par les pêcheurs dans l'année précédente (comme indicateur de la taille de la population de reproducteurs).

\section{Table III}

Summary of genetic variation for the River Nalon-Narcea Atlantic salmon population and average values for the region.

\section{Tableau III}

Résumé de la variation génétique de la population de saumon atlantique de la rivière Nalon-Narcea et valeurs moyennes pour la région.

\begin{tabular}{|l|c|c|c|}
\hline Parameter & Nalon-Narcea & Regional average & Reference \\
\hline Relatedness & -0.007 & 0 & Horreo et al. (2008) \\
\hline FIS & 0.036 & 0.031 & Horreo et al. (2008) \\
\hline Allelic richness & 11.271 & 10.436 & Horreo et al. (2008) \\
\hline Heterozygosity expected & 0.778 & 0.786 & Horreo et al. (2008) \\
\hline Heterozygosity observed & 0.75 & 0.761 & Horreo et al. (2008) \\
\hline \% foreign genomes (1992) & $1.50 \%$ & $3 \%$ & Moran et al. (2005) \\
\hline \% foreign genomes (1996) & $5 \%$ & $6.68 \%$ & Ayllon et al. (2006) \\
\hline
\end{tabular}

demand more strict population control. However there are no published studies with robust calculations of fish consumption by piscivorous birds in the region. In other regions like Scotland, where cormorants are salmonid predators (Kirby et al., 1996), shooting to reinforce scaring (not killing) is regarded as a favourable option; it could be also envisaged here.

Spanish anglers want to increase the number of salmon returning to Spanish rivers suggesting in second place that more salmon be introduced into the rivers. This approach does nothing to correct the basic problem of Spanish salmon rivers (impassable dams) and introduces hatchery-reared salmon into wild areas in the rivers to which they are poorly suited and may exert a negative impact on native populations (e.g. McGinnity et al., 2003; Moran et al., 2005; Ayllon et al., 2006; Jonsson and Jonsson, 2006). In fact, our results show that in 
the River Nalon-Narcea there was no significant association between stocking and catch despite high stocking efforts.

The failure of stocking as a strategy for increasing salmon run was not due to poor quality of stocked fish, as they were representative of the genetic variation of the native population (Horreo et al., 2008). Instead, it is more likely due to an intrinsic limitation of the carrying capacity of the available habitat. A more productive strategy would be to place native Spanish salmon into the local habitat that is currently inaccessible to salmon. This would allow the vacant habitat to produce smolts and could be done before fish passes are built at barrier dams. The quality of the native Nalon-Narcea river population seems to be very good, at least if compared with the rest of populations in the region (Table III). No inbreeding was detected, and the level of introgression of foreign genomes derived from past stock transfers was lower than in the other rivers of the region. Although hybridization was detected in the river in most years, apparently associated with salmon censuses (Figure 3) as abundance of salmon in a limited habitat may force spawning overlap with brown trout and increase occasions for interspecific mating, the level of introgression of heterospecific genomes through hybridization seems also to be low or negligible for the Nalon-Narcea river population (Castillo et al., 2008). Therefore, good conditions seem to exist for successful restoration of upstream areas presently devoid of salmon.

It is easier to predict how many parr can be supported by a unit of habitat in a good quality stream than it is to predict how many adults will return to the river. Ventura (1988) reported parr densities of 18 individuals $/ 100 \mathrm{~m}^{2}$ elsewhere in Spanish rivers and the rivers that we studied should be able to support a minimum of that many parr. However, in order for adults to successfully return to the River Trubia, fish must successfully migrate to sea as smolts, avoiding turbines at dams on the Trubia and Nalon Rivers. Although others have reported smolt return rates for Spanish rivers (e.g. Álvarez et al., 1995), each river has different challenges to smolts and different hydroelectric dams. For example, smolts must survive the degraded water quality in the lower River Nalon-Narcea (Ayllon et al., 2000). Weirs can exacerbate the effects of opportunistic predators, due to overcrowding of fish at downstream pools (Garcia de Leaniz, 2008); therefore, in addition to other dangers, smolts must survive predators in the lower river. It is impossible to know what smolt losses would occur between the nursery habitat and the sea. Once a fish survives to the adult stage and returns to the estuary, it must migrate past anglers and ascend fish passes at dams on the Rivers Nalon and Trubia before it can return to the area of the watershed that we studied near Proaza. Our calculations estimate the number of adult returns to the mouth of the River Nalon-Narcea. We made no attempt to model adult losses and fish pass efficiencies, nor smolt losses at the various hydroelectric dams, because such an exercise would be speculative as fish passes do not exist yet.

Surprisingly, the strategy of recovering salmon habitat upstream of present dams was suggested only by a minority of participants in the survey, which is logical because only a few participants (10\%) considered reduced habitat as a cause of population decline. It is also possible that they did not consider such possibility as feasible. Restoring salmon population upstream encompasses, however, some ecological and social problems. From the ecological side, it is likely that the new contact between Atlantic salmon and brown trout will enhance hybridization, as it will be a secondary contact (e.g. Vellend et al., 2007). The risk of endangering both native resident brown trout populations and the newly introduced Atlantic salmon thus exists via interspecific introgression, but also via competition and displacement from ecological niches. On the other hand, recovering new habitat for salmon would also require establishing new fishing regulations in upstream areas, now limited to brown trout fisheries. The new rules would likely be more restrictive, as the restored salmon population will initially require additional protection measures to facilitate adaptation. Public dissemination of scientific results has contributed to reinforcing public support of conservative management policies in other cases of exploited wild populations (Odum, 1993), therefore publicizing the information presented here via media and other forums (e.g., open seminars, fairs, talks to fishermen associations, and others) may contribute to open discussions and create opinions on this type of strategy. 


\section{ACKNOWLEDGMENTS}

We would like to acknowledge the assistance of our colleagues, without whose help this study would not have been possible: Fernando Ayllon and José Luis Martinez of the Universidad de Oviedo, and Diana Evans. This study was funded by the Fulbright Program for Joint SpanishNorth American Scientific and Technological Cooperation, Project 20044, and by the Spanish National project CGL2009-08279.

\section{REFERENCES}

Álvarez J., Lamuela M. and Castién E., 1995. Restoration Planning for the Atlantic salmon in the River Bidasoa (Navarra): First Results. In: Braña F. (ed.), Biologia y Conservacion del Salmon Atlantico (Salmo salar) en los rios de la region Cantabrica, ICONA, Madrid, 163-189.

Ayllon F., Suciu R., Gephard S., Juanes F. and Garcia-Vazquez E., 2000. Conventional armament wastes induce micronuclei in wild brown trout Salmo trutta. Mutation Res., 70, 169-176.

Ayllon F., Martinez J.L. and Garcia-Vazquez E., 2006. Loss of regional population structure in Atlantic salmon, Salmo salar L., following stocking. ICES J. Mar. Sci., 63, 1269-1273.

Bagliniere J.L. and Champigneulle A., 1986. Population estimates of juvenile Atlantic salmon (Salmo salar) as indices of smolt production in the River Scorff, Brittany. J. Fish Biol., 29, 467-482.

Bagliniere J.L., Marchand F. and Vauclin V., 2005. Interannual changes in recruitment of the Atlantic salmon (Salmo salar) population in the River Oir (Lower Normandy, France): relationships with spawners and in-stream habitat. ICES J. Mar. Sci., 62, 695-707.

Braña F., Garrido R., Reyes-Gavilan L.F., Toledo M.M. and Nicieza A.G., 1995. Distribution of Atlantic salmon in the Iberian peninsula. Location in the basin and within the context of fish assemblages. In: Braña F. (ed.), Biologia y Conservacion del Salmon Atlantico (Salmo salar) en los rios de la region Cantabrica, ICONA, Madrid, 13-25.

Castillo A.G.F., Ayllon F., Moran P., Izquierdo J.I., Martinez J.L., Beall E. and Garcia-Vazquez E., 2008. Interspecific hybridization and introgression are associated with stock transfers in salmonids. Aquaculture, 278, 31-36.

De Cola J.N., 1970. Water quality requirements for Atlantic salmon, Boston, MA, Northeast Region, U.S. Department of Interior- Federal Water Quality Administration.

De La Hoz J., 2001. Present status of Atlantic salmon in Asturias. In: Garcia de Leaniz C., Serdio A. and Consuegra S. (eds.), El salmon, joya de nuestros rios, Santander (Spain), Gobierno de Cantabria, Consejeria de Ganaderia, Agricultura y Pesca, 39-53.

Dopico E., Linde A.R. and Garcia-Vazquez E., 2009. Traditional and modern practices of soil fertilization: effects on cadmium pollution of river ecosystems in Spain. Hum. Ecol., 37, 235-240.

Garcia de Leaniz C., 2008. Weir removal in salmonid streams: implications, challenges and practicalities. Hydrobiologia, 609, 83-96.

Garcia de Leaniz C. and Martinez J.J., 1986. The Atlantic salmon in the rivers of Spain with particular reference to Cantabria. In: Mills D. and Piggins D. (eds.), Atlantic salmon: planning for the future, Croom Helm, London \& Sydney, 179-207.

Garcia-Vazquez E., Moran P., Martinez J.L., Perez J., de Gaudemar B. and Beall E., 2001. Alternative mating strategies in Atlantic salmon and brown trout. J. Hered., 92, 146-149.

Gephard S., 2008. Restoring Atlantic salmon (Salmo salar) to New England. In: Askins R.A. et al. (eds.), Saving Biological Diversity, New York, Springer Science, 39-53.

Harris C.M., Calladine J.R., Wernham C.V. and Park K.J., 2008. Impacts of piscivorous birds on salmonid populations and game fisheries in Scotland: a review. Wildlife Biol., 14, 395-411.

Heggenes J., Bagliniere J.L. and Cunjak R.A., 1999. Spatial niche variability for young Atlantic salmon (Salmo salar) and brown trout (S. trutta) in heterogeneous streams. Ecol. Freshwater Fish, 8, 1-21.

Horreo J.L., Machado-Schiaffino G., Griffiths A., Bright D., Stevens J. and Garcia-Vazquez E., 2008. Identification of differential broodstock contribution affecting genetic variability in hatchery stocks of Atlantic salmon (Salmo salar). Aquaculture, 280, 89-93.

Jonsson B. and Jonsson N., 2006. Cultured Atlantic salmon in nature: a review of their ecology and interaction with wild fish. ICES J. Mar. Sci., 63, 1162-1181. 
Kirby J.S., Holmes R.M. and Sellers R.M., 1996. Cormorants Phalacrocorax carbo as fish predators: An appraisal of their conservation and management in Great Britain. Biol. Conserv., 75, 191-199.

McGinnity P., Prodöhl P., Ferguson A., Hynes R., Maoiléidigh N.O., Baker N., Cotter D., O'Hea B., Cooke D., Rogan G., Taggart J. and Cross T., 2003. Fitness reduction and potential extinction of wild populations of Atlantic salmon, Salmo salar, as a result of interactions with escaped farm salmon. Proceedings of Biological Sciences, 270, 2443-2450.

McKernan J., 1991. Curriculum Action Reseach, A Handbook of Methods and Resources for the Reflective Practitioner, London, Kogan Page.

McLaughlin E.A. and Knight A.E., 1987. Habitat criteria for Atlantic salmon, Special Report, Laconia, New Hampshire, U.S. Fish \& Wildlife Service.

Moffitt C.M., Kynard B. and Rideout S., 1982. Fish passage facilities and anadromous fish restoration in the Connecticut River basin. Fisheries, 7, 2-11.

Moran P., Perez J., Dumas J., Beall E. and Garcia-Vazquez E., 2005. Stocking-related patterns of genetic variation at enzymatic loci in south European Atlantic salmon populations. J. Fish Biol. , 67, 186-200.

Nicieza A.G., Braña F. and Toledo M.M., 1991. Development of length-bimodality and smolting in wild stocks of Atlantic salmon, Salmo salar L., under different growth conditions. J. Fish Biol., 38, 509-523.

Odum E., 1993. Ecology and Our Endangered Life-Support Systems, Sunderland, Massachusetts, Sinauer Associates, Inc.

Parrish D.L., Behnke R.J., Gephard S.R., McCormick S.D. and Reeves G.H., 1998. Why aren't there more Atlantic salmon (Salmo salar)? Can. J. Fish. Aquat. Sci., 55 (Suppl. 1), 281-287.

Rifflart R., Marchand F., Rivot E. and Bagliniere J.L., 2006. Scale reading validation for estimating age from tagged fish recapture in a brown trout (Salmo trutta) population. Fish. Res., 78, 380-384.

Stake R.E., 1995. The art of case study research, Thousand Oaks, CA, Sage Publications.

Stanley J.G. and Trial J.G., 1995. Habitat suitability index models: non migratory freshwater life stages of Atlantic salmon, Biological Science Report 3, Washington D.C., U.S. Dept. of Interior.

Vellend M., Harmon L.J., Lockwood J.L., Mayfield M.M., Hughes A.R., Wares J.P. and Sax D.F., 2007. Effects of exotic species on evolutionary diversification. Trends Ecol. Evol., 22, 481-488.

Ventura J.A.M., 1988. The Atlantic salmon in Asturias, Spain: analysis of catches, 1985-1986. Inventory of juvenile densities. In: Mills D. and Piggins D. (eds.), Atlantic salmon: planning for the future, London, Croom Helm, 210-227. 